\title{
Recognition of gold mineralization favorability zones through airborne gamma-ray spectrometry and magnetometry in Brusque and Botuverá region, southern Brazil
}

\author{
Pereira, B.M., UFPR; Ferreira, F.J.F., UFPR
}

Copyright 2018, SBGf - Sociedade Brasileira de Geofísica

Este texto foi preparado para a apresentação no VIII Simpósio Brasileiro de Geofísica, Salinópolis, 18 a 20 de setembro de 2018 . Seu conteúdo foi revisado pelo Comitê Salinopolis, 18 a 20 de setembro de 2018. Seu conteúdo foi revisado pelo Comitê
Técnico do VIII SimBGf, mas não necessariamente representa a opinião da SBGf ou de seus associados. É proibida a reprodução total ou parcial deste material para propósitos comerciais sem prévia autorização da SBGf.

\begin{abstract}
The Brusque and Botuverá regions bear important granitic and volcano-exhalative related gold mineralization associated to potassic and phyllic alteration zones, remobilized by a structural reactivation phase. Radiometric data was used in correlation with geological units, while magnetometry was applied to define structural framework. Geophysical and geological data were integrated using knowledge driven method to define favorability zones. These data exhibited good correlation, as seen in the favorability map, which pointed important target areas for gold mineralization. It was also observed that structural framework exhibits more influence in the gold occurrences than hydrothermal alteration zones.
\end{abstract}

\section{Introduction}

The northeastern region of Santa Catarina state, south Brazil, is known for hosting important granitic and volcanic-exhalative gold mineralization, where several occurrences having been recognized and described. CPRM (1995) outlined potential gold exploratory targets by mapping the area, and Biondi et al. (2007) studied various magmatic-hydrothermal mineralization in Botuverá region, estimating ore reservoirs of 1 to 2 tons with $\mathrm{Au}$ content of 20 to $40 \mathrm{~g} / \mathrm{ton}$. Castro (1997) considered these gold mineralization occurrences to be the most important ones in Santa Catarina. Airborne geophysical surveys have been widely applied as supporting methods in geological mapping and mineral exploration. Gamma-ray spectrometry assists in the identification of hydrothermal potassic and phyllic zones, which can potentially be mineralized, while magnetometry helps in the delineation of the structural framework and recognition of magnetic rocks. Irvine \& Smith (1990) consider the use of radiometric and magnetic airborne surveys as a fundamental tool in regional and semiregional exploration phases, as coincident magnetic and potassium peaks are related to polymettalic deposits (Shives et al. 2000). Fornazzari \& Ferreira (2003) applied radiometric data to the identification of gold mineralization in Botuverá region, based on the analysis of gamma-ray profiles, finding important potential targets. This study aims to evaluate the concordance of geophysical data from the Paraná - Santa Catarina Aerogeophysical Project (CPRM, 2011) with the geological outline of the area, and interpret responses of radiometric and magnetic signals according to the lithological and structural features. Primary gold favorability zones were outlined based on geological-geophysical integration, using the knowledge driven analysis method.

The study area is located northeast of Santa Catarina state, south Brazil, and is limited by the coordinates $49^{\circ} 15^{\prime} 00^{\prime \prime} \mathrm{W}, 48^{\circ} 45^{\prime} 00^{\prime \prime} \mathrm{W}, 27^{\circ} 00^{\prime} 00^{\prime \prime} \mathrm{S}$ and $27^{\circ} 15^{\prime} 00^{\prime \prime} \mathrm{S}$, as shown in Fig. 1.

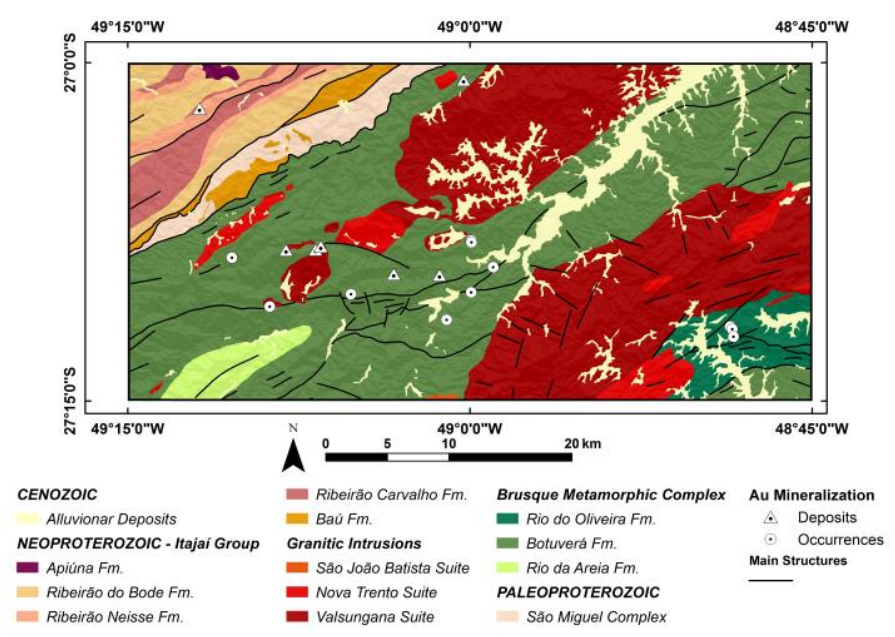

Figure 1: Study area geological context with main $A u$ occurrences.

\section{Data and Methods}

Geophysical data from Paraná - Santa Catarina Aerogeophysical Project (CPRM, 2011), geological data from Basei et al. (2014) and SRTM elevation model, all integrated into a GIS were applied.

The use of F Parameter (Efimov, 1978, apud Gnojek \& Prichystal, 1985) and Kd and Ud, from Saunders et al. (1994) allowed to observe hydrothermal processes. Magnetic data was reduced to the pole (Baranov, 1957; Macleod et al. 1993), then magnetic anomalies enhancing methods - THDR (Cordell \& Grauch, 1985), ASA (Nabighian, 1972), TDR (Miller \& Singh, 1994) and Signum Transform (de Souza \& Ferreira, 2013) were applied. Gamma-ray spectrometric data was interpolated by minimum curvature method, while magnetic data was gridded by bi-directional method and both disposed in a 100X100 meters grid. After gridding, F Parameter, Kd and Ud were generated based on corrected $\mathrm{K}$, eU and eTh grids, and after RTP, it was applied magnetic anomalies enhancing methods (Figs 7, 8, 9 and 10). 
The interpretation of radiometric anomalies was done by the identification of $\mathrm{K}$, eU and eTh distribution patterns, classified in different domains, and through magnetic anomalies it was recognized alignment patterns, classified according to their directions and interpreted as the structural framework. Favorability zones were defined by knowledge driven method. Within this method, Index Overlay was employed by applying Boolean operations (Bonham Carter, 1997; Nóbrega, 2001). Variables were selected based on primary gold model, of magmatichydrothermal or volcano-exhalative type, both influenced by structural reactivation, and classified as favorable or non-favorable. Variables were geological units: granitic intrusions and the metavolcano-exhalative unit, plus a 500 meters wide influence zone (weight 2); magnetic lineaments divided into $\mathrm{NE}+\mathrm{EW}$ directions (weight 3 ), and NW direction (weight 1), plus a 250 meters influence zone; areas where $\mathrm{F}$ Parameter and $\mathrm{Kd}$ values were over the mean plus one standard deviation (weight 2), plus a 500 meters influence zone; and known mineralization, classified in mineral occurrences (weight 1) and deposits (weight 2), plus a 500 meters influence zone.

\section{Results}

The gammaspectrometric domains (Fig. 2) were defined classifying the concentrations of radioelements in low, medium or high. It was recognized 14 domains, which exhibited a relation with the geological context especially in granitic intrusions. In other sections a partial correlation is seen, probably caused by the fact that radiometry measures only the surface's first $40 \mathrm{~cm}$.

Quartzitic, basic, carbonatic and calc-silicatic-composition units exhibited the lowest concentrations $(A, B, C$ and $D$ domains). In contact metamorphism zones, uranium and thorium are higher (E, $\mathrm{H}$ and $\mathrm{J}$ domains), probably caused by hydrothermal or post-magmatic processes. $\mathrm{F}$ and $\mathrm{N}$ domains, with high eU concentrations, coincides with granitic intrusions, which are composed of biotite-rich granites. I domain, characterized by high potassium, coincides with north and central intrusions, probably associated to feldspar and to potassic alteration. Units composed by conglomerates, arkoses and argillites from Itajaí Group, represents $\mathrm{G}$ domain. Units predominantly arenitic presents low potassim and uranium, and are represented by $\mathrm{K}$ domain. $\mathrm{L}$ domain is represented by the northern part of the São Miguel Complex (SMC), with high contents of $\mathrm{K}$ and Th, but low $\mathrm{U}$.

Magnetic lineaments (Fig. 3) were traced and interpreted as structures. It was observed three structural trends: NE, EW and NW. NE lineaments vary from N30E-N50E, and were related to thrust and transcurrent faults and shear zones.

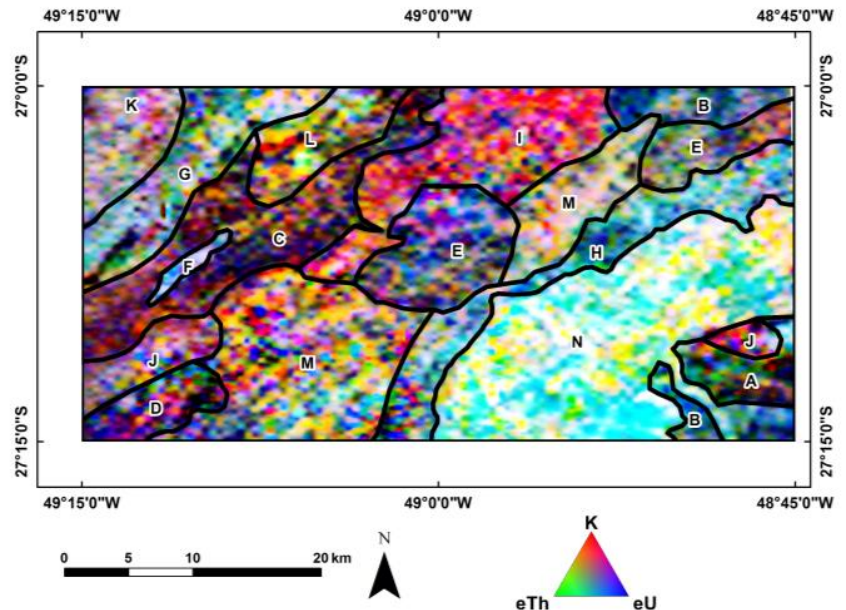

Figure 2: Gamma-ray spectometric domains and ternary K-eTh-eU map.

Three sets of NE lineaments were observed, disposed in the northwestern, central and southeastern areas. The northwest portion is related to Itajaí Perimbó Shear Zone (IPSZ) and to SMC, and exhibits a sinuous and braided pattern. The central set is associated with high to low angle shear zones. Many gold mineralization are aligned to this group. The southeastern group of lineaments is related to structures hosted in South Valsungana intrusion. EW lineaments were interpreted as inflections of central NE group, and also show a relation to gold mineralization (Fig. 4). NW lineaments exhibit a long and continuous pattern, homogeneously distributed. These lineaments are vary from N30W-N50W, and many of those coincides with positive structures in terrain, which were interpreted as basic dykes.

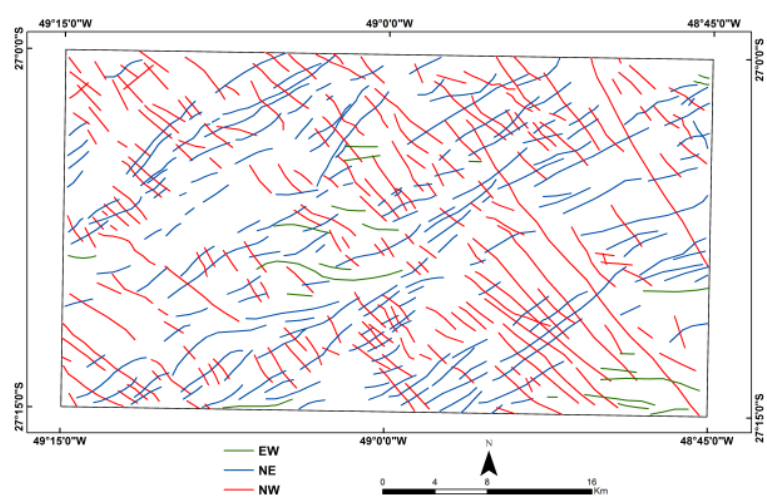

Figure 3: Magnetic lineaments classified according to its directions. 


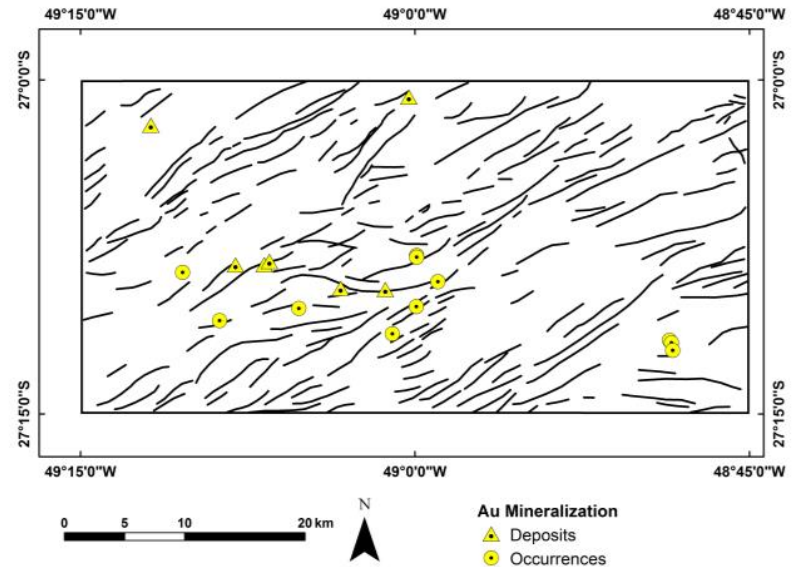

Figure 4: Magnetic NE-direction lineaments and gold mineralization.

A ternary map with potassium (red), thorium (green) and TDR (blue) was used in radiometric and magnetic integration (Fig. 5), as suggested by Irvine \& Smith (1990). This map allowed to notice that metarhythmitic units shows a depletion of both radioelements and TDR, probably associated to quartz-rich rocks. The border of granitic intrusions, shear zones and basic NW dykes exhibit high TDR values, whereas the inner portion of granitic intrusions exhibit high eTh and TDR. This is possibly associated to a high presence of $\mathrm{K}$-feldspar and to hydrothermalism, as described by Biondi et al. (2007) and Hueck et al. (2016). The Faxinal granitic intrusion presents lower concentration of potassium in relation to uranium and thorium. The Ribeirão Carvalho formation of the Itajaí Group, composed of siltic-argillaceous rocks, is distinguished by higher concentrations of thorium. The other units present greater $\mathrm{K}$ content, possibly related to arkoses interleaved with turbidites of Ribeirão Neisse formation. This ternary map showed that eTh and K-rich zones associated with $\mathrm{K}$ and TDR areas, or zones of $\mathrm{K}$, Eth and TDR high values are frequently related to gold mineralization, suggesting the influence of hydrothermal and structural processes.

The favorability map values (Fig. 6) varied from 0 to 10 , and were organized in five classes: very low (0-1), low (13 ), medium (3-5), high (5-7) and very high (7-10). It was observed that medium to very high favorability zones hosts known gold occurrences, and these zones coincides with propitious areas for mineralization, but some zones also occurs in non-coherent geological environments. Due to this disparity, 20 areas were targeted amongst those with higher chance to host gold mineralization.

\section{Discussion and Conclusions}

Through the integration of geophysical and geological data, it was possible to recognize favorable areas for the occurrence of primary gold mineralization. The gammaray spectrometry presented considerable correlation to geological units, as can be seen by its domains and correspondent lithotypes.



Figure 5: K-eTh-TDR ternary maps and gold mineralization.



Figure 6: Favorability zones map and the targeted areas.

The delimitation of the domains revealed similarity with granitic intrusions and contact metamorphism zones, and a correlation with the São Miguel Complex, the Brusque Metamorphic Complex and the Itajaí Group. In the BMC, it was possible to distinguish quartz-rich, basic or carbonatic/calc-silicatic units from micaceous, phyllitic, feldspatic or argillaceous to siltic units.

Magnetometry revealed an important connection between low to high angle shear zones, which cross the study area and with Mesozoic-age basic dykes with magnetic lineaments, making it possible to identify three main directions: NE, EW and NW. It was also found that NE lineaments located at the center of the area, just as EW lineaments, have an important relation to gold mineralization, as suggest by Biondi et al. (2007). NW lineations correspond to diabase dykes and Mesozoicrelated structures, like faults and joints.

The geophysical-geological integration revealed that the central portion of the study area holds the highest probability to host gold mineralizations, many of which are not known occurrences, indicating great potential for gold exploration. It was also noted that gold occurrences are more related to magnetometry than to gamma-ray spectrometry, suggesting that NE structures are more important for mineralization than potassic and phyllic hidrothermalism associated to granites. 


\section{Acknowledgements}

We are grateful to CPRM (Companhia de Pesquisa de Recursos Minerais - Geological Survey of Brazil) for allowing us to use and publish airborne geophysical data in the study area. F.J.F. Ferreira was supported in this research by National Council for Scientific and Technological Development (CNPq), under contract 306978/2015-6.

\section{References}

Baranov, V. 1957. A new method for interpretation of aeromagnetic maps: pseudo-gravimetric anomalies. Geophysics, vol XXII (2): 259-383.

Basei, M. A. S.; Campos Neto, M. C.; Castro, N. A.; dos Santos, P. R.; Siga Jr., O.. 2014. Mapa Geológico. Folha Vidal Ramos SG.22-Z-D-I. Escala 1:100.000

Biondi, J. C.; Franke, N. D.; Carvalho, P. R. S. De; Villanova, S. N. 2007. Geologia do depósito de Au Cavalo Branco (Botuverá - SC). Revista Brasileira de Geociências, 37: 445-463.

Bonham-Carter, G.F. 1997. GIS methods for integrating exploration data sets. In: Proceedings of exploration 97: fourth decennial international conference on mineral exploration, ed. A.G Gubins, 59-64.

Castro, N.A. 1997. Contribuição ao Conhecimento Geológico - Metalogenético Associado aos Granitoides Intrusivos no Grupo Brusque (SC) com Base em Informações geológicas, aerogamaespectrométricas e LANDSAT T/TM-5. 221p. Dissertação de Mestrado. Universidade Estadual de Campinas, Campinas.

Companhia de Pesquisa de Recrsos Minerais, 1995. Folha Botuverá SG.22-Z-B-IV-22. Botuverá, Mapa Geológico, escala 1:50.000.

Companhia de Pesquisa de Recursos Minerais. 2011. Programa Geologia do Brasil (PGB) - Projeto Aerogeofísico Paraná - Santa Catarina. Relatório final do levantamento e processamento dos dados magnetométricos e gamaespectrométricos. $326 \mathrm{p}$.

Cordell. L.; Grauch, V. J. S. 1985. Mapping basement magnetization zones from aeromagnetic data in the San Juan Basin, New Mexico. In: W.J. Hinze (ed), The utility of regional gravity and magnetic anomalies maps. Society of Exploration Geophysicists, SEG, 181-197.

Fornazzari Neto, L.; Ferreira, F. J. F. 2003. Gamaespectrometria integrada a dados exploratórios multifonte em ambiente SIG aplicada à prospecção de ouro na Folha Botuverá, SC. Revista Brasileira de Geociências, 33 (2): 197-208.
Gnojek, I., Prichystal, A. 1985. A new zinc mineralization detected by airbone gamma-ray spectrometry in Northern Moravia (Czechoslovakia). Geoexploration, 23 (4), 491 502.

Hueck, M.; Basei, M. A. S.; Castro, N. A. 2016. Origin and evolution of the granitic intrusions in the Brusque Group of the Dom Feliciano Belt, south Brazil: petrostructural analysis and whole-rock/isotope geochemistry. Journal of South American Earth Sciences, 69: 131-151.

Irvine, R. J.; Smith, M. J. 1990. Geophysical exploration for epithermal gold deposits. Journal of Geochemical Exploration, Amsterdam, 36: 375-412.

MacLeod,. I.N.; Jones, K.; Dai, T. F. 1993. 3-D analytic signal in the interpretation of total magnetic field data at low magnetic latitudes. Exploration Geophysics, 24: 679688.

Miller, H. G.; Singh, V. 1994. Potential field tilt - A new concept for location of potential field sources. Journal of Applied Geophysics, 32, 213-217.

Nabighian, M. N. 1972. The analytic signal of twodimensional magnetic bodies with polygonal crosssection: Its properties and use for automated anomaly interpretation. Geophysics, 37, 507-517.

Nóbrega, R. P. 2001. Análise espacial 'knowledge-driven' e 'data-driven': o uso das lógicas boolena, fuzzy e redes neurais para geração de mapas favorabilidade mineral na região centro-leste da Bahia. Dissertação de Mestrado. Universidade Estadual de Campinas, Campinas.

Saunders, D. F.; Branch, J. F.; Thompson, C. K. 1994. Tests of aerial radiometric data for use in petroleum reconnaissance. Geophysics, 59: 411-419.

Shives, R. B. K.; Charbonneau, B. W.; Ford, K. L. 2000. The detection of potassic alteration by gamma-ray spectrometry - Recognition of alteration related to mineralization. Geophysics, 65 (6): 2001-2011.

de Souza, J., Ferreira, F. J. F., 2013. On the use of derivatives for interpreting magnetic anomalies due to dyke-like bodies II: application to synthetic and field data. In: 2013 SEG Annual Meeting. Society of Exploration Geophysicists, pp. 1121-1125. 


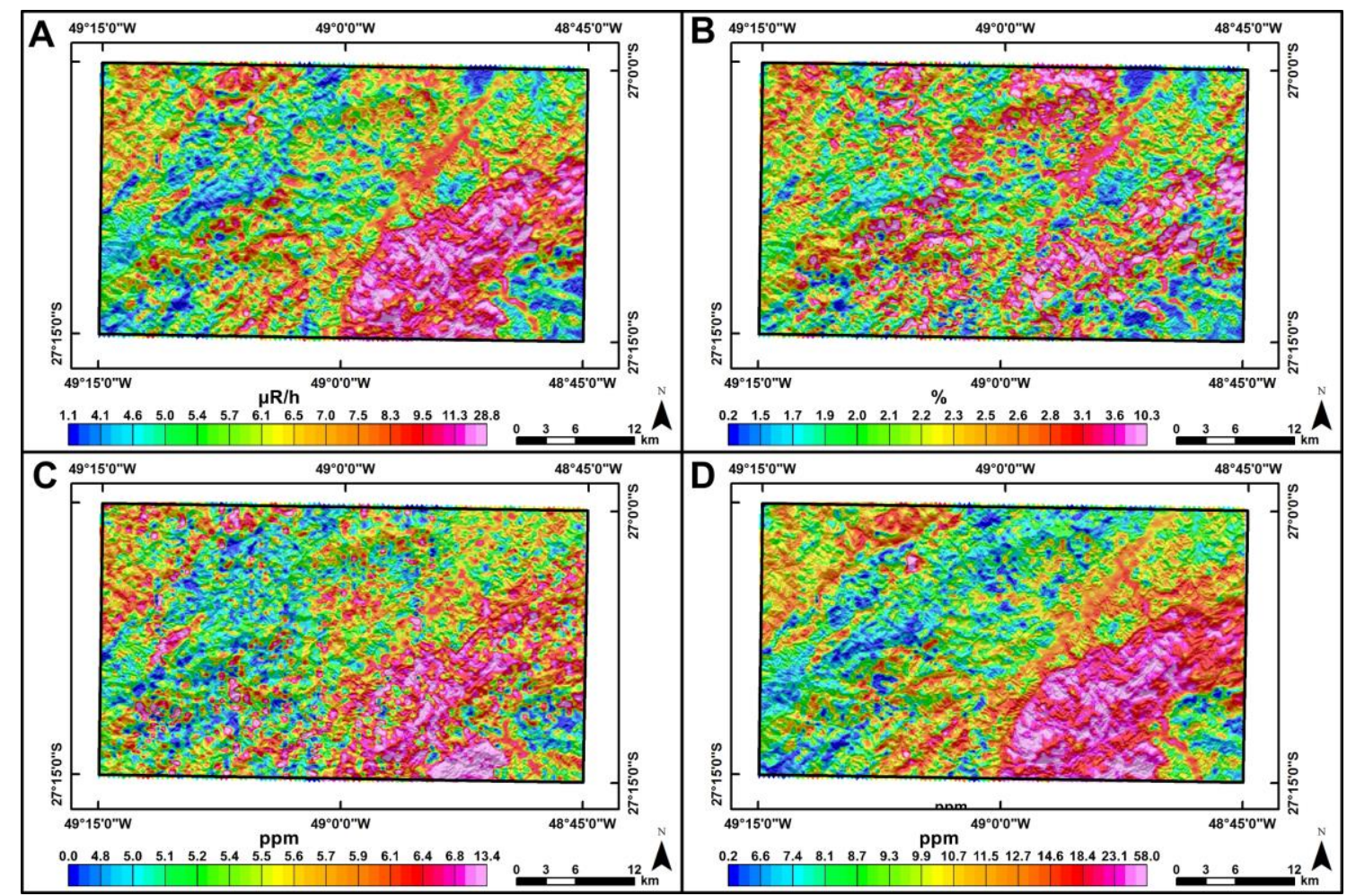

Figure 7: Gamma-ray spectrometric maps: A) Total Count. B) Potassium. C) Thorium equivalent. D) Uranium equivalent.



Figure 8: Gamma-ray spectrometric maps: A) Ternary K-eTh-eU. B) F Parameter. C) Kd. D) Ud. 


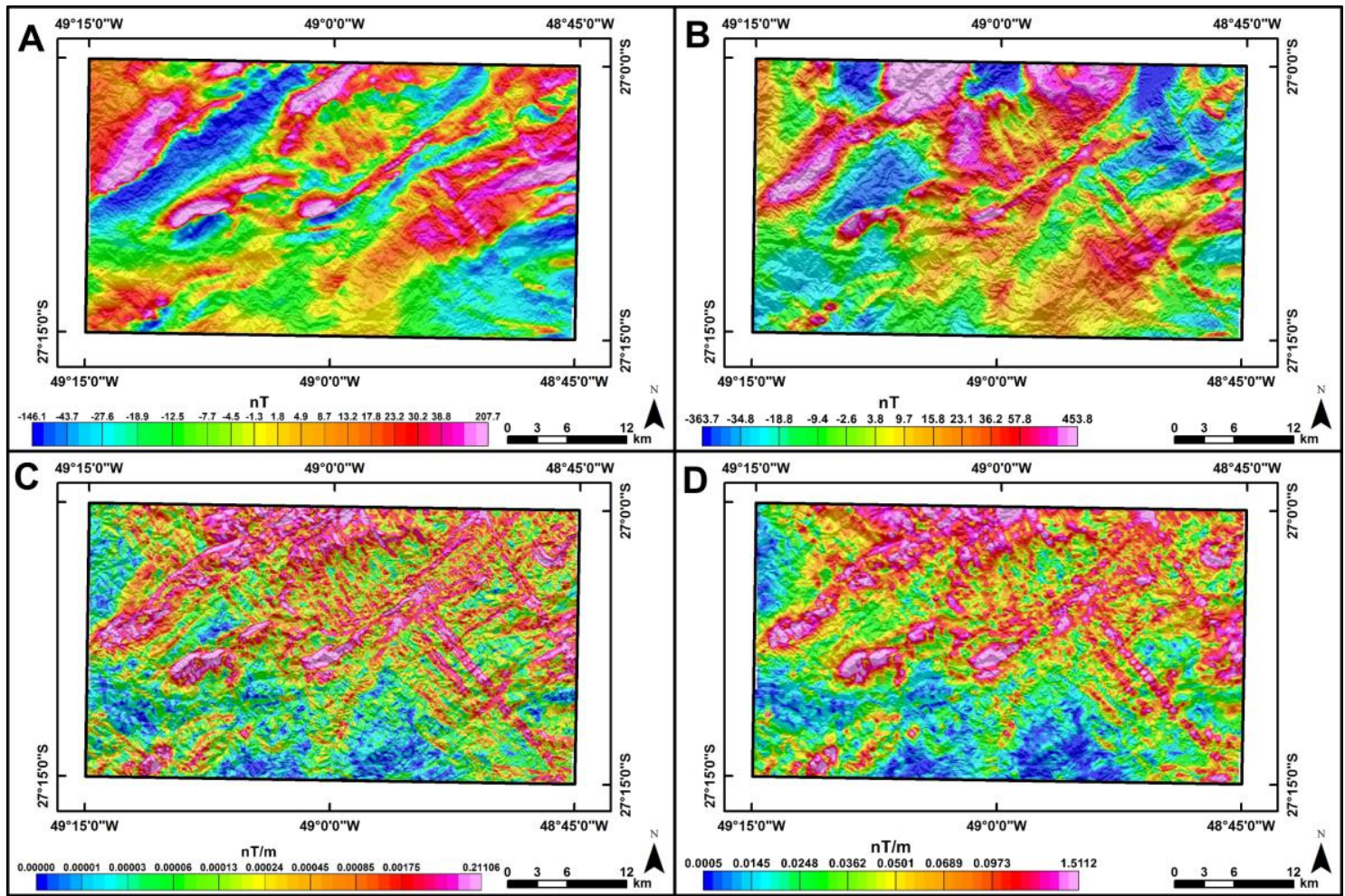

Figure 9: Magnetic maps: A) TMI. B) Reduced to the pole (RTP). C) THDR. D) ASA.



Figure 10: Magnetic maps: A) TDR. B) TDR-THDR. C) Signum Transform. 